\title{
Mineralogy and the Texture of the Basalt in Hail Region, Saudi Arabia
}

\author{
Sana'a Odat \\ Department of Earth and Environmental Sciences, Faculty of Science, Yarmouk University, Irbid, Jordan \\ Email: Sanaa.owdat@gmail.com, Sanaa.owdat@yu.edu.jo
}

Received 14 March 2014; revised 10 April 2014; accepted 18 April 2014

Copyright @ 2014 by author and Scientific Research Publishing Inc. This work is licensed under the Creative Commons Attribution International License (CC BY). http://creativecommons.org/licenses/by/4.0/

c) (i) Open Access

\section{Abstract}

The study is carried out to list mineralogy and texture of the basalt in Hail region. The basalt flows belong to the Arabian Harrat volcanism. Cenozoic volcanism has produced 13, vast, basaltic fields in western Saudi Arabia, covering a total area of about $100,000 \mathrm{sq}$. $\mathrm{km}$. The volcanism starts in the late Cretaceous time and continues periodically into the Holocene. The basaltic field presently investigated is known as Harrat Al-Hamad (or Harrat As-Shamah) which lies in northwestern Saudi Arabia, and continues northwards into Jordan. Mineralogical analysis of 20 rock samples indicates that the rocks are products of continental intra-plate magmatism; mostly as coarse-grained silica-under saturated olivine-rich alkali basalt. Mineralogical study shows that rocks are olivine, plagioclase, pyroxene, Nepheline and Opaque minerals. They correspond to alkali olivine basalts. Moreover, the main well-defined texture is intergranular, vesicular and amygdaloidal texture.

\section{Keywords}

Mineralogy, Texture; Hail, Basalt, Alkali Olivine, Saudi Arabia

\section{Introduction}

Basalts are the most abundant extrusive igneous rocks, which have erupted on earth throughout its history. Their most extrusive forms are lava flows and pillows in which they constitute the bulk of the major lava plateau on the continents, ocean floor and significant parts of volcanic in rift valleys. Basalt as a general term is a finegrained, mafic volcanic rock containing (44-54)\% $\mathrm{SiO}_{2}$. It consists essentially of calcic plagioclase and abundant mafic minerals mainly Ca-rich clinopyroxene, but may contain quartz, orthopyroxene, olivine, feldspathoid, small proportions of alkali feldspar ( $<10 \%$ total feldspar), Fe-Ti oxides and apatite. Basalt rocks may give many types according to their mineralogical compositions such as tholeiite contains quartz, hypersthene basalt con- 
tains hypersthene, olivine tholeiite contains hypersthene and olivine, olivine basalt; contains olivine, and alkali basalt which contains nepheline [1].

Basalts are often associated with lava flows and narrow dykes and sills. Most of basalts occur as lava flows either in volcanoes or as extensive sheets building up a lava plateau, which may cover hundreds of thousands of square kilometers, and may be fed by numerous fissures. The surface forms of lavas are of two principal types; smooth or ropy (the surface looks like a rope) which is known by the Hawaiian term of pahoehoe, and scoriaceous which is rough and clinker and has the Hawaiian name A'A. Another common form is pillow lava which consists of pillows or balloon-like masses of basalt — usually with a very fine-grained or glassy outer layer. They are the major constituent of the upper layer of the ocean floors (usually as pillow lava), and hot spot volcanoes such as the Hawaiian Islands. Basalt commonly forms on the continents too, usually the result of hot spot activity. Here it may also exist as intrusive dikes and sills, or extrusive cinder volcanoes [2].

Harrat Al-Shaam is a large intra-continental basalt terrain, which covers an area of about $50,000 \mathrm{~km}^{2}$, about $25 \%$ of the Arabian Harrat. It stretches over $700 \mathrm{~km}$ in a NW-SE direction and extends over the southern rim of the Damascus Basin in Syria. It is marked by the folded mountain of Antilebanon, southwards through NorthJordan up to the northern rim of Al-Azraq depression, and then to the "Al-Nofuth" desert in the northwestern part of Saudi Arabia [3].

The basalt originated during several phases of eruptions, which were closely associated in space and time with: 1) the Cainozoic evolution of the Red Sea through two-stages of spreading; the first was before $30-15 \mathrm{Ma}$ and the second was initiated over the past 5 Ma-recent; 2) collision of the Arabian and Eurasian plates and 3) the uplift of the Afro-Arabian dome [4].

Previous studies on the North Arabian volcanic province suggest that the derivation of this basalt from deep mantles source material and that it is also characterized by a low degree of partial melting of upper mantle peridotites with the minor secondary differentiation [5] [6]. The depth of the basalt source material is $37-60 \mathrm{~km} \mathrm{[7].}$

\section{Materials and Methods}

\subsection{The Study Area}

Volcanic activity that accompanied the opening of the Red Sea from the Miocene (25 Ma) to the present, resulted in the formation of vast fields of subaerial basaltic flows in the western part of Saudi Arabia, referred to by the Arabic term "Harrat". These harrats cover an area over about $90,000 \mathrm{~km}^{2}$, and extending over parts of the Proterozoic Arabian shield and adjacent Phanerozoic rocks of the Arabian Platform and Red Sea basin [4] [8]. The principal harrats are Harrat Rahat, Harrat Uwayrid, Harrat al Hutaymah, Harrat Kishb, Harrat Khaybar, and Harrat al Birk. The lava flows are commonly composed of picritic to ankaramitic basalt and may contain peridotite nodules (Figure 1) [9].

The study area is located in the southern part of Hail region. It is located between $27^{\circ} 13^{\prime} \mathrm{N} \& 27^{\circ} 31^{\prime} \mathrm{N}$ and $42^{\circ} 09^{\prime} \mathrm{E} \& 42^{\circ} 35^{\prime} \mathrm{E}$. The principal features of the region are the two great mountain ranges of Aja (granites) and Salma (basalts) and the immense rolling sand dunes of An-Nafüd [10].

In order to determine the mineralogical and texture characteristics of basaltic rocks of Hail region, twenty representative samples (as fresh as possible) were collected and studied under the polarizing microscope.

\subsection{Methodology and Techniques}

Twenty rock samples have been collected from the study area. Thin sections were studied under polarizing microscope.

\subsubsection{Thin Section Preparation}

Thin sections were prepared as follows: A slab of basalt with $30 \mathrm{~mm} \times 20 \mathrm{~mm} \times 10 \mathrm{~mm}$ thick was cut, polished using $(200,400,800,1000)$ silicon carbide powder, in order to get a smooth surface easy to stack with glass slide of $(26 \times 42 \mathrm{~mm})$, using Canada palsam adherent. An Automated thin section machine, called Multiplate Grinder housed was used for making the slides thinner in thickness of approximately 45 microns. Then, Heavy duty polishing table and hand polishing using (1000) silicon carbide, grinded the slide down to 30 microns [11].

\subsubsection{Polarizing Optical Microscope}

Nikon optical microscope, are used particularly to identify mineral constituents of the studied basaltic rocks, and 


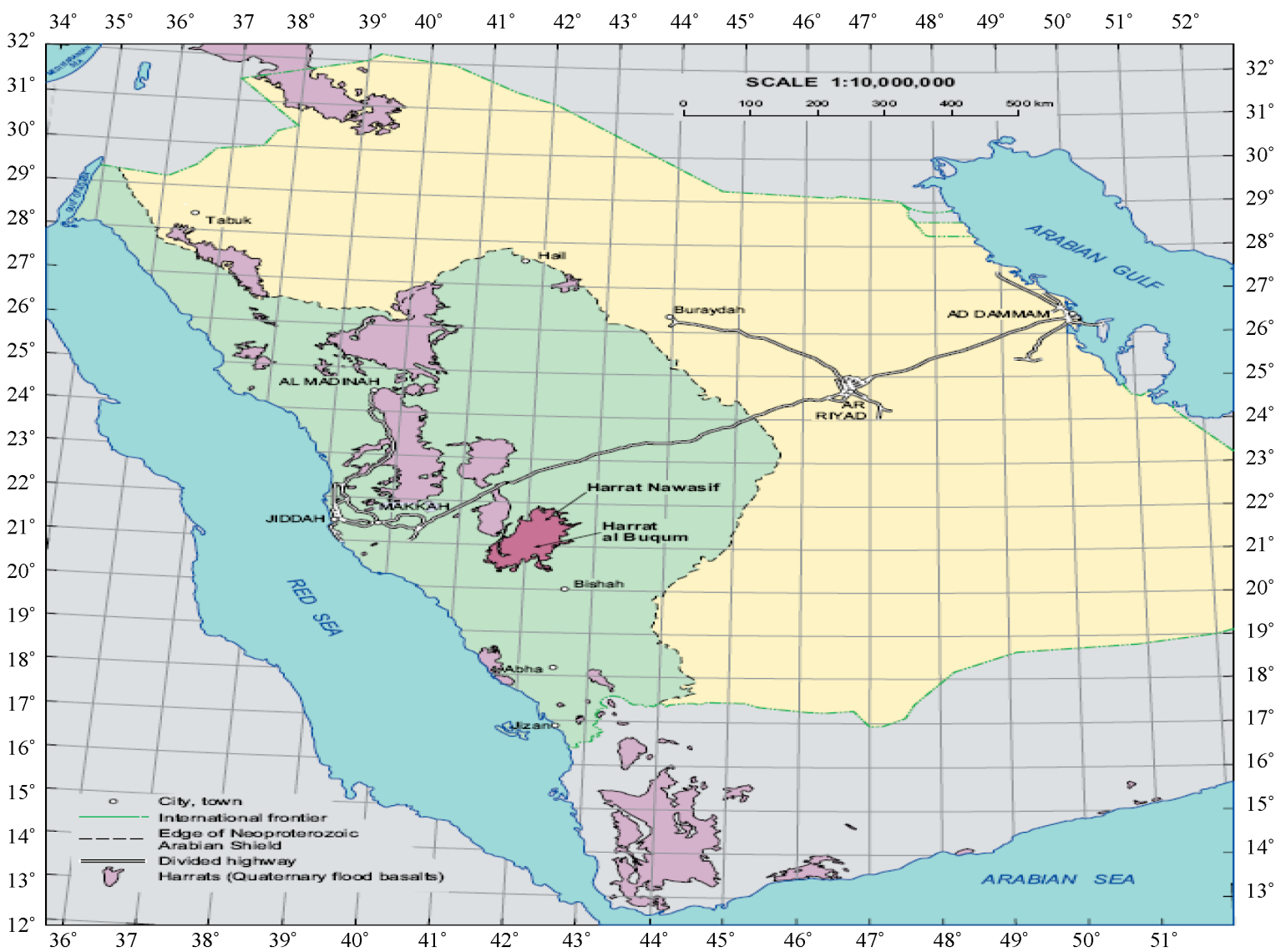

Figure 1. Map showing the major Cenozoic lava fields of Saudi Arabia.

to determine the mineralogical properties and textures.

\section{Result}

\subsection{Minerals Description}

\subsubsection{Primary Minerals}

\section{1) Olivine}

Olivine is the major mineral phase in the studied basalts, rates between 8 vol $\%$ and 11 vol $\%$. It usually present as subhedral to anhedral, light grey to colorless crystals. Olivine crystals are characterized by high relief, parallel extinction crystals that exhibit two generations of size, which rather variable reflecting a seriate texture, as phenocrysts and groundmass . They range in size between $0.01 \mathrm{~mm}$ and $2 \mathrm{~mm}$ in all samples (Figure 2).

Olivine minerals of different flows don't exhibit twining. However, all basalt flows show corroded olivine crystals, due to resorbtion, the shaping of the resorbtion of olivine can be noted through the bands of iddingsite that forms a long their embayment rims (Figure 3).

Olivine minerals had been subjected to alteration processes, such as hydration and oxidation, the processes represented by a slight chlorite and much iddingsite that occur at the rims, along the fractures of the crystals core and rarely completely at the whole olivine crystal. Iddingsite appears as a dark red, slightly pleochroic brown color.

\section{2) Plagioclase}

Plagioclase is the most abundant mineral phase in the studied basalts, which ranges from 20 vol\% to 44 vol\%, this variation is due to the cooling rate, as well as the thickness of the flow where the lowest flow is the thickest. Plagioclase phenocrysts occur as lath-like Clusters of phenocrysts up to 7 crystals forming a golmeroporpheritic texture. The second flow is crystallized by one generation as phenocrysts (Figure 4), they are com- 


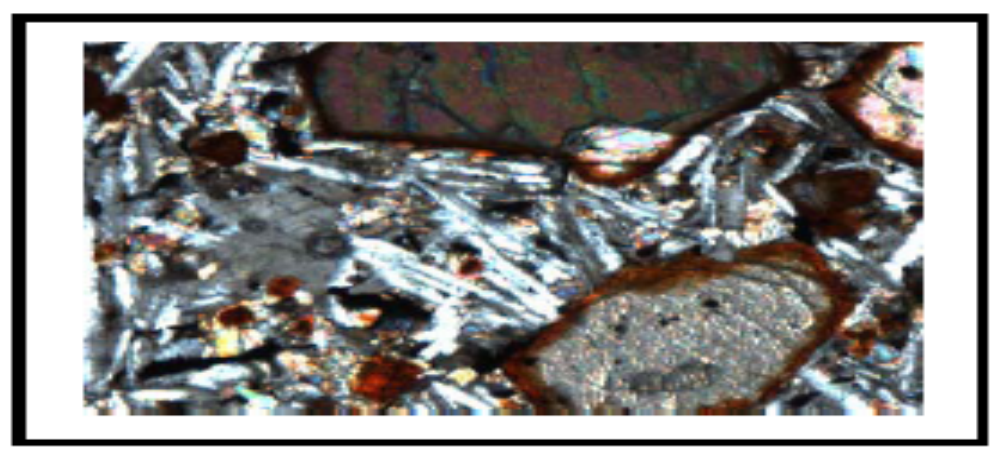

Figure 2. Microphotograph showing of olivine crystals under PPL $(\times 10)$.

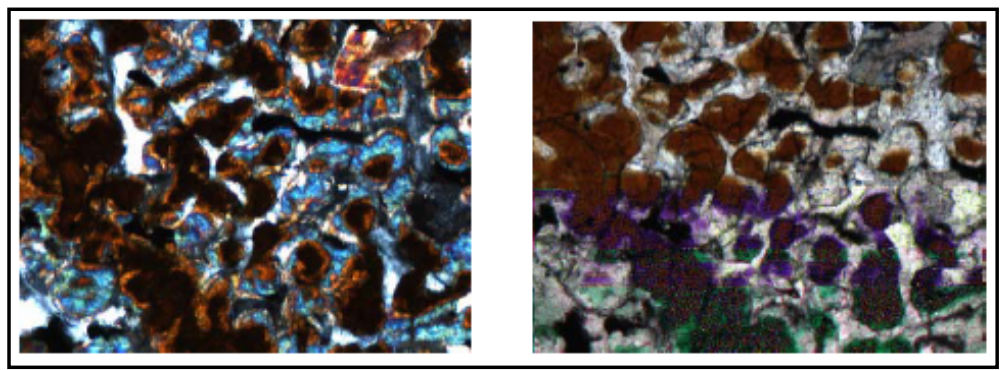

(a)

(b)

Figure 3. Microphotograph showing resorbtion of olivine crystals: (a) Under PPL; (b) $\mathrm{CN}(\times 10)$.

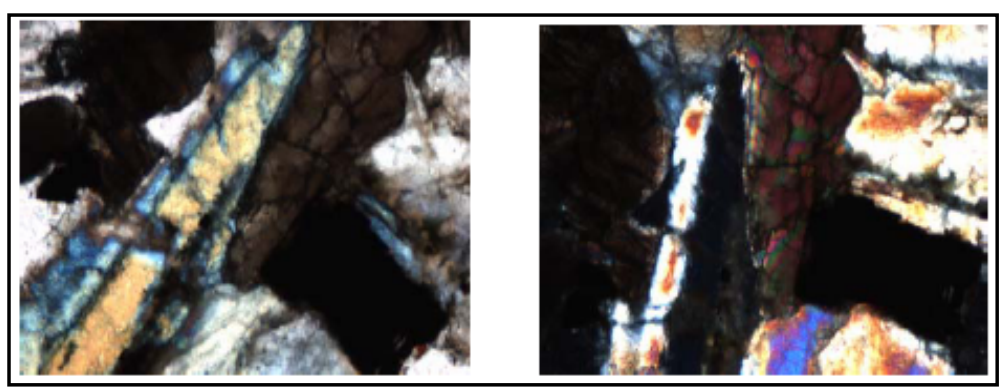

(a)

(b)

Figure 4. Microphotograph of plagioclase crystals (a) Under PPL; (b) CN $(\times 10)$.

monly lath-like shape.

Plagioclases phenocrysts are subhedral, but some are euhedral and tabular in shape and colorless crystals exhibit two sets of cleavage intersects at $90^{\circ}$. Groundmass plagioclase occurs as skeletal like microlites. The crystals are slightly fractured. Polysenthetic or multiple twining is common, simple twining are also noted, the multiple twining lamellae are wide, using the MICHEAL-LEVY method [12]. Plagioclase laths were found to have extinction angle between $38^{\circ}$ to $42^{\circ}$, indicates a labradorite (An 59-An68) and anorthite (An 100-An 80) range of composition. Sericitisation of plagioclase is common, that appear as pale yellow color band at the outer most rims of the crystals, some of them affect the inner most parts of the crystals (Figure 5).

\section{3) Pyroxene}

Pyroxene are grayish brown in color with anhedral crystals and can be distinguished by two sets of cleavage intersects in $90^{\circ}$. The abundance of pyroxene is ranging between $12 \mathrm{vol} \%$ to $20 \mathrm{vol} \%$, as one generation (phenocrysts) in all samples. Pyroxene crystals have an inclined extinction which represents clinopyroxene minerals, this inclination is measured and found to be between $\left(36^{\circ}-42^{\circ}\right)$, that indicates diopside mineral of composition. These crystals have subhedral to anhedral oxides inclusions of magnetite type. Pyroxene crystals also had been 
affected by the alteration processes which appear as a green chlorite on the fractures, crystal rims and on the cleavage sets (Figure 6).

\section{4) Nepheline}

Nepheline crystals are colorless under plane polarized light and forms about 2 vol $\%$ of the rock. The crystals are euhedral to subhedral in shape and exhibit two sets of cleavage that are intersected at $90^{\circ}$. They have parallel extinction and biaxial interference figure. It is noticed that they are slightly fractured and slightly altered along rims and cleavage planes, (Figure 7).

\section{5) Opaque minerals}

Opaque minerals is abundant - as inclusions within olivine and pyroxene crystals. Generally, they are black, and show homogeneous optical properties. Most of them are anhedral to subhedral (rod-like), rarely magnetite shows four sided octagonal shape (Figure 8).

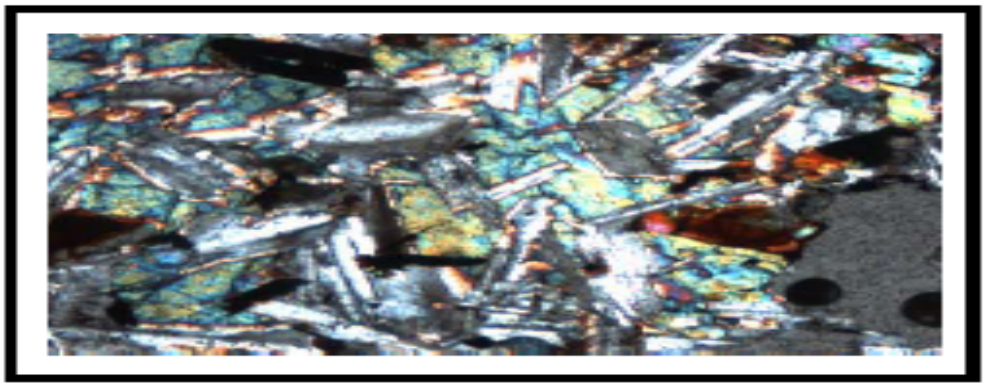

Figure 5. Microphotograph showing the serisitsation of plagioclase crystals under PPL $(\times 10)$.

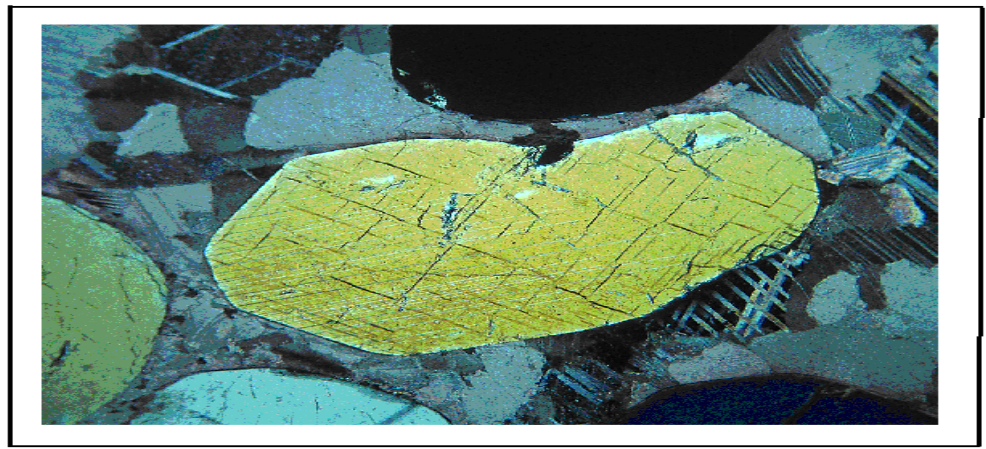

Figure 6. Microphotograph showing the pyroxene crystals under PPL $(\times 10)$.

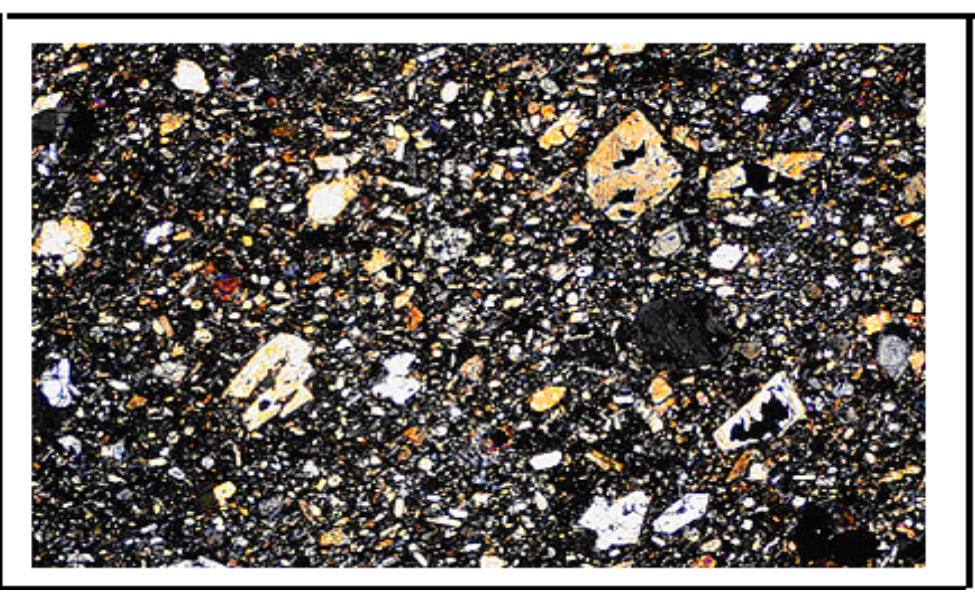

Figure 7. Microphotograph showing the Nepheline crystals under PPL $(\times 10)$. 


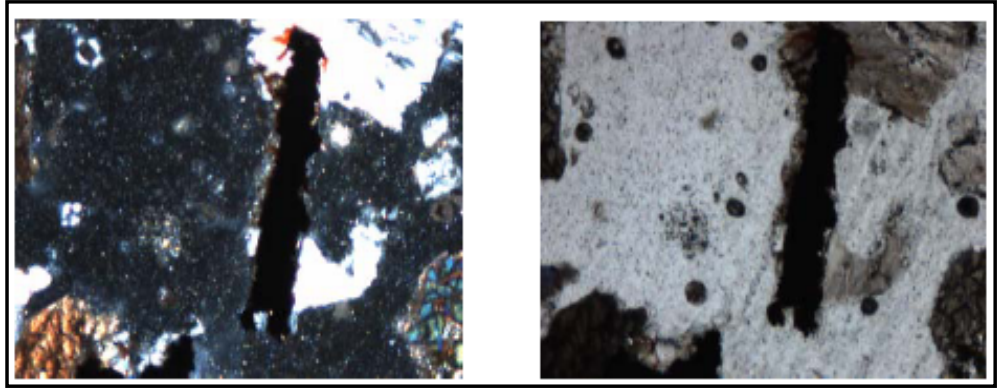

(a)

(b)

Figure 8. Microphotograph showing rod like oxides shape, (a) Under PPL; (b) $\mathrm{CN}(\times 10)$.

\subsection{Secondary Minerals}

Several secondary (authogenic) minerals are formed due to the post eruption processes such as hydration and oxidation of the original pyrogenic minerals. These processes include oxidation of olivine, albitization and seritisation of plagioclases and chloritisation of pyroxene. The microscopic investigations show that the second flow was suffered from alteration.

Sericite: pale yellow to turbid color, along the rims and twining planes of the crystals, formed about $5 \%$ of the highly weathered, and mainly distributed the original characteristics of the plagioclase, this disturbing affecting the extinction of the crystals and the original color of the mineral.

Iddingsite: the studied thin sections suffered from highly to slight iddingtisation, however particularly this psedomorphism of olvine to iddengsite is noted mostly as a dark brown to reddish brown to yellowish orange and mostly recorded along the rims and fractures of crystals and occasionally forming about ( $5-15 \mathrm{vol} \%)$ of crystals.

Chlorite: Chloritization is seen by the occurrences of chlorite along the edges of clino pyroxene (augite) and occasionally along cleavage sets. They are green. Some pyroxenes are completely chloritized.

\subsection{Textures Description}

The texture for all basalt flows is found to be intergranular texture (Figure 9), vesicular texture (Figure 10) and amygdaloidal textures (Figure 11).

\section{Discussion}

\subsection{Mineralogy}

The basalt samples in hand specimen are melanocratic, holocrystalline, medium-grained, and porphyritic. Vesicles have an elongated and oval shape. Moreover, the main mineral constituents are olivine, plagioclase, pyroxene, and opaque minerals (mainly magnetite). The secondary minerals include iddingsite, sericite, and chlorite. Common textures occurring are intergranular, vesicular and amygdaloidal textures.

\subsubsection{Olivine}

Olivine occurs as phenocrysts and in groundmass. The phenocrysts are euhedral to subhedral. They are colourless to pale greys. Olivine in the groundmass has subhedral to rounded shape. The larger crystals are fractured slightly - to-moderately. Iddingtization is common, particularly along fractures and along edges of the crystals. Some crystals are partially to completely pseudomorphed to dull brown iddingsite. Groundmass olivine is also iddingsitized.

\subsubsection{Plagioclase}

Plagioclase occurs in two generations as larger phenocrysts and as small tabular to elongated microlites in the groundmass. The phenocrysts are subhedral laths. The extinction angles on several plagioclase phenocrysts range from $28^{\circ}$ to $32^{\circ}$, indicating a labradorite composition (An50-An70) by using the method described by Michel-Levy's [12]. 


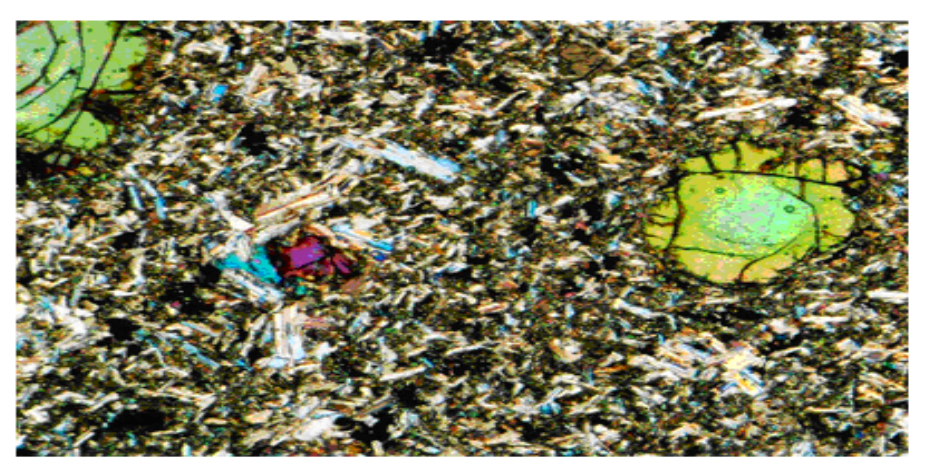

Figure 9. Microphotograph showing be intergranular texture.

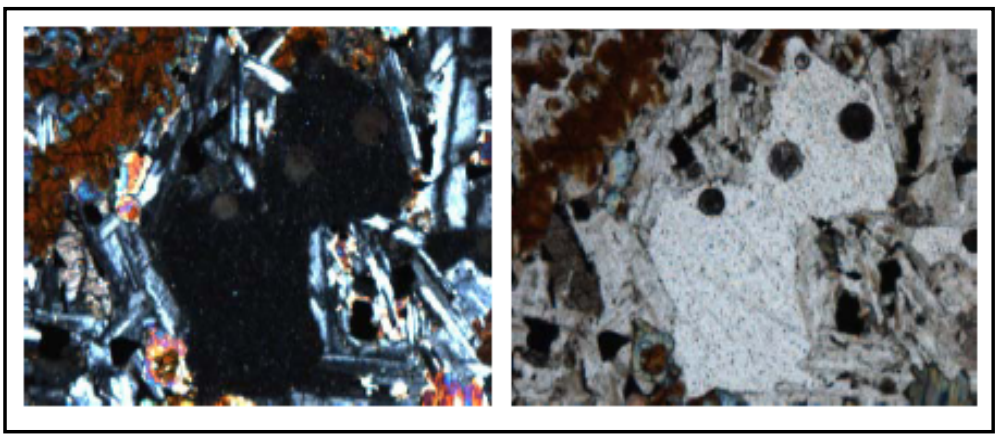

(a)

(b)

Figure10. Microphotograph showing vesicle net shape, (a) Under PPL; (b) $\mathrm{CN}(\times 10)$.

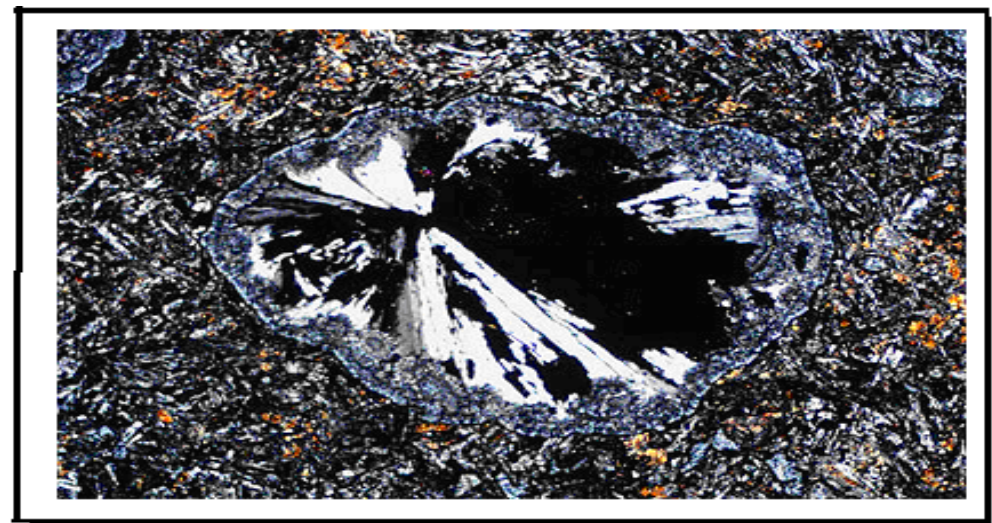

Figure 11. Microphotograph showing be amygdaloidal texture.

\subsubsection{Pyroxene}

Pyroxene occurs as brownish anhedral crystals. The pyroxene crystals have an inclined extinction of between $\left(36^{\circ}-42^{\circ}\right)$, that indicates diopside mineral of composition. Pyroxene crystals are affected by chloritization. Green chlorite is present along fractures and along crystal rims.

\subsubsection{Opaque Minerals}

Opaque minerals are mostly magnetite phenocrysts scattered throughout the rock and throughout inclusions within olivine and pyroxene crystals. Generally, magnetite is black; and shows homogeneous optical properties. Most of it is anhedral to subhedral, but crystals with square outline are also presented. 


\subsubsection{Groundmass}

The groundmass consists mainly of plagioclase (labradorite), olivine, pyroxene (diopside), and opaque minerals (mainly magnetite). Sericite, iddingsite and chlorite are secondary minerals.

\section{Conclusion}

Minerological studies of selected basalt samples from Hail region show that the basalts are generally composed of primary minerals such as olivine,plagioclase and pyroxene. Olivine is considered the most common essential mineral phase, followed by plagioclase pyroxene, Nepheline and opaque minerals. Secondary minerals are sericite, iddingsite and chlorite. Quartz is totally absent. Presence of olivine as phenocrysts as well as in the groundmass (more iron rich, similar to one described by [13]-[15] is a common feature of alkali olivine basalts.

\section{Acknowledgements}

The author would like to express her deep thanks to Dr. Ahmad Alshammari from Hail University for his help in providing the geological information and samples from Hail region in Saudi Arabia.

\section{References}

[1] Shalley, D. (1993) Igneous and Metamorphic Rocks under the Microscope. Springer, London, 234 p.

[2] Solyom, Z., Andreasson, P. and Johansson, I. (1985) Petrochemistry of Late Proerozoic rift Volcanism in Scandinavia, Mafic Dike Swarms in Constructive and Abortive Arms. Abstract Book, 164-171.

[3] Al-Malabeh, A., El-Hasan, T., Lataifeh, M. and O'Shea, M. (2002) Geochemical- and Mineralogical-Related Magnetic Characteristics of the Tertiary-Quaternary (Umm A-Qutein) Basaltic Flows from the Basaltic Field of Harra El-Jabban, Northeast Jordan. Physica B: Condensed Matter, 321, 396-403. http://dx.doi.org/10.1016/S0921-4526(02)01083-9

[4] Camp, V. and Roobol, M., (1989) The Arabian Continental Alkali Province: Part I Evolution of Harrat Rahat, Kingdom of Saudi Arabia. Geological Society of. America Bulletin, 101, 71-95. http://dx.doi.org/10.1130/0016-7606(1989)101<0071:TACABP>2.3.CO;2

[5] Barberi, F., Capaldi, G., Gasperini, P., Marinelli, G., Santacroce, R., Scandone, R., Treuil, M. and Varet, J., (1979) Recent Basaltic Volcanism of Jordan and Its Implications on the Geodynamic Evolution of the Afro-Arabian Rift System. Rome, 667-683.

[6] Saffarini, G, Nassir, S. and Abed, A. (1985) A Contribution to the Petrology and Geochemistry of the QuaternaryNeogene Basalts of Central Jordan. Dirasat, 12, 133-144.

[7] Ibrahim, K. (1996) The Regional Geology of Al-Azraq Area. NRA. Geol. Dir. Map Div. Bull, 36, 67.

[8] Coleman, R. and McGuire, A. (1983) Magma Systems Related to the Red Sea Opening. Tectonophysics, 150, 77-100. http://dx.doi.org/10.1016/0040-1951(88)90296-X

[9] Thornber, C.R. (1990) Geologic Map of Harrat Hutaymah, with Petrologic Classification and Distribution of Ultramafic Inclusions. Saudi Arabia: US Geological Survey Map MF-2129.

[10] Al-Turki, T.A. and Al-Qlayan, H.A. (2003) Contribution to the Flora of Saudi Arabia: Hail Region. Saudi Journal of Biological Sciences, 10, 190-222.

[11] Hughes, C. (1982) Igneous Petrology. Development in Petrology. Elsevier, New York.

[12] Kerr, P. (1977) Optical Mineralogy. John Wiley and Sons, New York.

[13] Brown, G.M. (1968) Mineralogy of Basaltic Rocks. In: Hess, H.H. and Poldervaart, A., Eds., Basalts, Vol., I., Interscience, John Willey and Sons, New York, 103, 160-162.

[14] Nagao T. and Sakaguchi, Y. (1990) Ultramafic Xenoliths in the Cenozoic Kawashimo Alkali Basalt from Masuda, Shimane Prefecture SW Japan. Journal of Mineralogy, Petrology and Economic, 17, 21-27. http://dx.doi.org/10.2465/ganko.85.469

[15] Shoji, A. and Natsue, A. (1995) Reaction of Orthopyroxene in Peridotite Xenoliths with Alkali Basalt Melt and Its Implication of Genesis of Alpine Type Chromitite. American Mineralogist, 80, 1041-1047. 